Atmos. Chem. Phys., 11, 9787-9801, 2011

www.atmos-chem-phys.net/11/9787/2011/

doi:10.5194/acp-11-9787-2011

(C) Author(s) 2011. CC Attribution 3.0 License.

\title{
Snow optical properties at Dome C (Concordia), Antarctica; implications for snow emissions and snow chemistry of reactive nitrogen
}

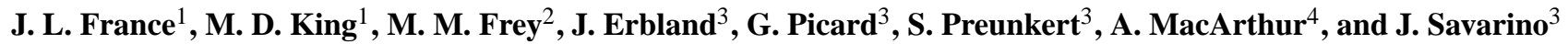 \\ ${ }^{1}$ Department of Earth Sciences, Royal Holloway University of London, Egham, Surrey, TW20 0EX, UK \\ ${ }^{2}$ British Antarctic Survey, Highcross, Madingley Road, Cambridge CB3 0ET, UK \\ ${ }^{3} \mathrm{UJF}$ - Grenoble 1 / CNRS, Laboratoire de Glaciologie et Géophysique de l'Environnement (LGGE) UMR 5183, \\ Grenoble, 38041, France \\ ${ }^{4}$ NERC Field Spectroscopy Facility, Grant Institute, School of GeoSciences, University of Edinburgh, \\ Edinburgh, EH9 3JW, UK
}

Received: 24 March 2011 - Published in Atmos. Chem. Phys. Discuss.: 18 April 2011

Revised: 2 September 2011 - Accepted: 5 September 2011 - Published: 21 September 2011

\begin{abstract}
Measurements of $e$-folding depth, nadir reflectivity and stratigraphy of the snowpack around Concordia station (Dome C, $75.10^{\circ} \mathrm{S}, 123.31^{\circ} \mathrm{E}$ ) were undertaken to determine wavelength dependent coefficients ( $350 \mathrm{~nm}$ to $550 \mathrm{~nm}$ ) for light scattering and absorption and to calculate potential fluxes (depth-integrated production rates) of nitrogen dioxide $\left(\mathrm{NO}_{2}\right)$ from the snowpack due to nitrate photolysis within the snowpack. The stratigraphy of the top $80 \mathrm{~cm}$ of Dome C snowpack generally consists of three main layers:- a surface of soft windpack (not ubiquitous), a hard windpack, and a hoar-like layer beneath the windpack(s). The $e$-folding depths are $\sim 10 \mathrm{~cm}$ for the two windpack layers and $\sim 20 \mathrm{~cm}$ for the hoar-like layer for solar radiation at a wavelength of $400 \mathrm{~nm}$; about a factor 2-4 larger than previous model estimates for South Pole. The absorption cross-section due to impurities in each snowpack layer are consistent with a combination of absorption due to black carbon and HULIS (HUmic LIke Substances), with amounts of $1-2 \mathrm{ng} \mathrm{g}^{-1}$ of black carbon for the surface snow layers. Depth-integrated photochemical production rates of $\mathrm{NO}_{2}$ in the Dome $\mathrm{C}$ snowpack were calculated as $5.3 \times 10^{12}$ molecules $\mathrm{m}^{-2} \mathrm{~s}^{-1}, 2.3 \times 10^{12}$ molecules $\mathrm{m}^{-2} \mathrm{~s}^{-1}$ and $8 \times 10^{11}$ molecules $\mathrm{m}^{-2} \mathrm{~s}^{-1}$ for clear skies and solar zenith angles of $60^{\circ}, 70^{\circ}$ and $80^{\circ}$ respectively
\end{abstract}

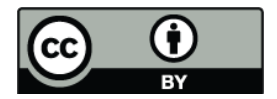

Correspondence to: M. D. King

(m.king@es.rhul.ac.uk) using the TUV-snow radiative-transfer model. Depending upon the snowpack stratigraphy, a minimum of $85 \%$ of the $\mathrm{NO}_{2}$ may originate from the top $20 \mathrm{~cm}$ of the Dome $\mathrm{C}$ snowpack. It is found that on a multi-annual time-scale photolysis can remove up to $80 \%$ of nitrate from surface snow, confirming independent isotopic evidence that photolysis is an important driver of nitrate loss occurring in the EAIS (East Antarctic Ice Sheet) snowpack. However, the model cannot completely account for the total observed nitrate loss of 90$95 \%$ or the shape of the observed nitrate concentration depth profile. A more complete model will need to include also physical processes such as evaporation, re-deposition or diffusion between the quasi-liquid layer on snow grains and firn air to account for the discrepancies.

\section{Introduction}

It is well documented that the photolysis of the nitrate anion $\left(\mathrm{NO}_{3}^{-}\right)$in the surface snowpack is a source of $\mathrm{NO}_{2}$ to the atmosphere above, with experiments in both North and South polar regions demonstrating that $\mathrm{NO}_{\mathrm{x}}$ fluxes are emitted from the snowpack under sunlit conditions (e.g. Jones et al., 2001; Domine and Shepson, 2002; Honrath et al., 2002; Oncley et al., 2004). The main reaction pathways for the emission of $\mathrm{NO}_{\mathrm{x}}$ are shown in Reactions (R1-R3) whereas full

Published by Copernicus Publications on behalf of the European Geosciences Union. 
details of snowpack photochemistry are reviewed in Grannas et al. (2007).

$\mathrm{NO}_{3}^{-}+h v \rightarrow \mathrm{NO}_{2}+\mathrm{O}^{-}$

$\mathrm{NO}_{3}^{-}+h v \rightarrow \mathrm{NO}_{2}^{-}+\mathrm{O}\left({ }^{3} \mathrm{P}\right)$

$\mathrm{NO}_{3}^{-}+h v \rightarrow \mathrm{NO}_{2}+\mathrm{O}^{-}$

$\mathrm{NO}_{2}^{-}+\mathrm{OH} \rightarrow \mathrm{NO}_{2}+\mathrm{OH}^{-}$

The reaction (R1a) has been demonstrated in the laboratory to be more efficient than (R1b) in both aqueous solution (Warneck and Wurzinger, 1988) and ice (Dubowski et al., 2001). The amount of $\mathrm{NO}_{2}$ photochemically produced is dependent upon the concentration of nitrate within the snowpack, snowpack temperature, and the intensity of solar radiation within the snowpack. The intensity of solar radiation penetrating into the snow is dependent upon the light scattering and absorption properties of the snowpack and the solar zenith angle. The snowpack can be split into two depth regimes based upon the propagation of solar radiation into the snow: a top layer, a few $\mathrm{cm}$ thick where direct solar radiation is converted into diffuse radiation, and a second layer, the asymptotic zone, below the top layer, in which, the solar radiation is effectively all diffuse and the intensity of the radiation decays exponentially (e.g. Warren, 1982).

The production of $\mathrm{NO}_{2}$, within the snowpack provides a source of $\mathrm{NO}_{\mathrm{x}}$ to the overlying atmosphere with large mixing ratios of NO (relative to remote regions) having been measured in boundary layer air at the South Pole and across the Antarctic plateau during several field campaigns (e.g. Davis et al., 2001, 2004, 2008; Slusher et al., 2010). It is hypothesised that for highly enhanced $\mathrm{NO}_{\mathrm{x}}$ mixing ratios, in part due to the continued photochemical release of $\mathrm{NO}_{\mathrm{x}}$ from the snowpack as air masses travel over the Antarctic plateau, cause the enhanced ozone concentrations measured over the South Pole (Neff et al., 2008; Legrand et al., 2009).

At locations with a low snow accumulation rate, such as Concordia Station (Dome C, $75.10^{\circ} \mathrm{S}, 123.31^{\circ} \mathrm{E}$ ) on the Antarctic plateau (7.2 $\mathrm{cm} \mathrm{yr}^{-1}$; Rothlisberger et al., 2002; Wolff et al., 2002), nitrate deposited in the snow will spend a longer period of time nearer the surface than nitrate deposited in regions with higher snow accumulation rates such as Summit, Greenland (accumulation rate of $65 \mathrm{~cm} \mathrm{yr}^{-1}$; Dibb and Fahnestock, 2004). The availability of nitrate at the snow surface, or near to the snow surface, for long periods of time increases the probability that it will be photolysed and that photolysis products will be lost to the atmosphere before it is buried to sufficient depth to be preserved in icecore records. In Greenland, several studies have investigated the nitrate concentration depth profile and the preservation of nitrate into ice-core records. In high accumulation areas, such as Summit, the preservation of the nitrate concentration depth profile is assisted by the large snow accumulation and up to $75-90 \%$ of nitrate is preserved (Burkhart et al., 2004; Dibb et al., 2007). Unlike the Antarctic plateau, the complexity of the nitrate record in Greenland is increased by the contribution from anthropogenic input (Hastings et al., 2004). In regions of the Greenland ice-sheet, the observed, preserved, nitrate concentration depth profile cannot be explained through accumulation processes alone and requires photochemistry, evaporation and sublimation to explain the loss of nitrate (Burkhart et al., 2008). Field and laboratory data suggest nitrate photolysis is an important, possibly even the dominating process in removing nitrate from the snow on the Antarctic plateau as gaseous nitrogen species (Chu and Anastasio, 2003; Frey et al., 2009). A quantitative interpretation of the nitrate concentration depth record from long ice core records such as the 800 kya old EPICA (European Project for Ice Coring in Antarctica) ice core recovered at Dome $\mathrm{C}$ is currently not possible since the understanding of post-depositional processes affecting nitrate is not complete (Jouzel et al., 2007; Wolff et al., 2010). An initial model study concluded that photochemistry can only account for $40 \%$ of the nitrate loss observed for the South Pole, with other post depositional processes being required to explain the depth profiles observed (Wolff et al., 2002). Isotopic evidence from laboratory photolysis experiments appeared to support this view (Blunier et al., 2005), however Frey et al. (2009) showed that the laboratory results, and thus the conclusions drawn in Blunier et al. (2005) do not apply to the snow environment at the Earth's surface, including Dome C. To the contrary, a model for photolytic isotopic fractionation explains, within the analytical uncertainties, the enrichment of the nitrogen stable isotope in snow nitrate observed at Dome $\mathrm{C}$ and in previous lab experiments, suggesting that photolysis is an important process driving isotopic fractionation and associated nitrate loss from snow, specifically in the low accumulation regions of the East Antarctic Ice Sheet (Frey et al., 2009). However, more details on snow optical properties and how solar radiation propagates in snow are needed in order to further quantify processes contributing to post-depositional isotopic fractionation and changes in snow chemical concentrations. The latter is of high relevance for the interpretation of ice core records recovered at the EPICA drilling site (e.g. Rothlisberger et al., 2000; Wolff et al., 2010).

In the work described here, the snowpack optical properties at Dome $\mathrm{C}$ from field measurements of snow surface reflectance and light penetration into the snowpack are determined. The measurement of snowpack optical properties has been shown to be complex as underlying snow layers can affect measurements of surface snow albedo if the albedos of the two layers are thin and significantly different (Aoki et al., 2003), it has also been widely demonstrated that reflectivity is sensitive to grain shape and grain size (e.g. Wiscombe and Warren, 1980; Munneke et al., 2008; Picard et al., 2009). Using field data with an 8-stream DISORT (DIScrete Ordinates Radiative-Transfer) (Stamnes et al., 1988) model, 
TUV-snow (Tropospheric Ultraviolet Visible - snow) (LeeTaylor and Madronich, 2002), the production of $\mathrm{NO}_{2}$ owing to nitrate photolysis within the Antarctic Plateau snowpack is calculated. Further, a comparison to the work of Wolff et al. (2002) and to $\mathrm{NO}_{\mathrm{x}}$ flux measurements made during Antarctic Plateau field campaigns is undertaken, updating the modelling work of Wolff et al. (2002) using new field measurements obtained in this work.

The aims of this work were:

1. An experimental, field-based, determination of the optical properties of Dome $\mathrm{C}$ surface snowpack to compare with measurements of other snowpack sites.

2. Calculation of depth-integrated production rates of $\mathrm{NO}_{2}$ within Dome $\mathrm{C}$ snowpack, and comparison with previously modelled and measured fluxes of $\mathrm{NO}_{\mathrm{x}}$ from Antarctic snows.

\section{Methods}

The work was a field and modelling study of the Dome C snowpack, and each aspect (field and modelling) is described separately. The fieldwork characterised the optical properties of the Dome $\mathrm{C}$ snowpack that were required to calculate the depth-integrated production rates of $\mathrm{NO}_{2}$ from photolysis of snowpack nitrate. The depth-integrated production rate may be interpreted as the upper limit for a potential molecular flux from the snowpack to the atmosphere of $\mathrm{NO}_{2}$.

To estimate depth-integrated production rates of $\mathrm{NO}_{2}$ from the Dome $\mathrm{C}$ snowpack the 8-stream coupled snowatmosphere radiative-transfer model TUV-snow was used (Lee-Taylor and Madronich, 2002). The TUV-snow model parameterises the snowpack in terms of light scattering and absorption coefficients. To determine the optical coefficients of absorption and scattering requires measurements of light penetration depth ( $e$-folding depth) into the snow, snowpack reflectance and snow density.

\subsection{Field Methods}

Surveys of the snowpack at Dome C, with 14 snowpits at sites $1 \mathrm{~km}$ South, $5 \mathrm{~km}$ East and $1 \mathrm{~km}$ West of the Base, demonstrated that the top metre of snow cover consists of typically 3 distinct layers (with minor perturbations), and it is appropriate to consider the optical properties for each layer individually to allow the determination of optical coefficients for each layer.

\subsubsection{Light penetration depth (e-folding depth) measurements}

From the measurements of in-snow irradiance at several depths within the snowpack, $e$-folding depths were calcu- lated according to the Beer-Bouger Lambert law (1), for each of the three snowpack layers.

$$
I_{z}=I_{z^{\prime}} e \frac{\left(z-z^{\prime}\right)}{\varepsilon(\lambda)}
$$

where $I_{z}$ is the intensity at a depth $z$ within the snowpack, $z^{\prime}$ is the initial depth in the snowpack, $z$ is a deeper depth than $z^{\prime}$, and $\varepsilon(\lambda)$ is the asymptotic $e$-folding depth (the depth at which incident diffuse irradiance has been reduced to $1 / e$ $(\sim 37 \%)$ of its initial value) for a specific wavelength, $\lambda$. The $e$-folding depth of the snowpack is calculated from measurements of the in-snow irradiance at different depths within the asymptotic zone (Fisher et al., 2005).

The in-snow irradiance of the Dome $\mathrm{C}$ snowpack was measured within 14 separate snowpits at three areas in the vicinity of Dome C (all within $5 \mathrm{~km}$ ). For each snowpit, stratigraphy was recorded to gain an understanding of the natural variation in layer thickness, but only the layers greater than $25 \mathrm{~cm}$ thick were selected for $e$-folding depth and albedo measurements.

Each snowpit was approximately $1.5 \mathrm{~m}$ by $1 \mathrm{~m}$ by $1 \mathrm{~m}$ deep, and the irradiance penetrating into the snowpack was recorded using a custom-built 6 spectrometer (6 channels and fibre optics connected to individual spectrometers) instrument with components from Ocean Optics. The spectrometer components are taken from Ocean Optics USB2000 + spectrometers. The method used here is a progression and improvement to the single fibre-optic or single spectrometer method used during previous campaigns to measure snowpack optical properties (King and Simpson, 2001; Fisher et al., 2005; Beine et al., 2006). The spectrometers were powered through a single USB cable connected to a Panasonic toughbook computer allowing true field portability. Each spectrometer had its own fibre optic probe with a cosine corrector, which was placed horizontally into the fresh, shaded snowpack face and recorded UV-Visible irradiance $(\lambda=320-700 \mathrm{~nm}, \Delta \lambda \leq 1 \mathrm{~nm})$ within the snowpack at varying depths in a single stratigraphic layer. The integration time of each measurement was varied between $50 \mathrm{~ms}$ and $10 \mathrm{~s}$, in order to obtain a good signal-to-noise ratio with the length of integration time dependent upon the depth of the fibre optic probe. The signal to noise ratio was typically better than 1:300. The vertical spacing between each fibre was approximately $3-5 \mathrm{~cm}$ where the thickness of the snowpack layer allowed, and no fibres were placed within $3 \mathrm{~cm}$ of a snow layer boundary. Optical measurements of thick layers ensures the variation of solar irradiance within the snow layer was measured over two or more $e$-folding depths in each layer. The fibres were displaced horizontally by $10-30 \mathrm{~cm}$. A relative intensity calibration of the spectrometers and fibre optics was performed by simultaneously measuring the intensity of the solar radiation above the snowpack. Dark spectra (electrical noise) were recorded in the field by capping each of the fibre optic probes. A wavelength calibration for each spectrometer was performed using 
a mercury-argon lamp in the field. The 6 spectrometer instrument records at different depths simultaneously, thus no correction for changing sky conditions is required. The $e$ folding depth does not depend upon the absolute irradiance, measured by each spectrometer, and therefore there is no need for an absolute irradiance calibration of the fibre optic probes or spectrometer efficiency, although a travelling NIST illumination standard was used to monitor equipment for quality assurance purposes and long term drift. Irradiance spectra for each fibre optic probe were post processed by wavelength binning, removing dark spectra and normalising to one of the spectra from another fibre optic. An $e$ folding depth was calculated for each wavelength by fitting the measured irradiance for that wavelength to Eq. (1).

Repeatability of $e$-folding depth measurements has been studied in detail by France et al. (2011) and quantified as $\pm 20 \%$. The large uncertainty is a combination of snow variability and measurement uncertainty. The uncertainty was calculated using four depth measurements and using an inferior single spectrometer instrument and is expected to be a maximum error for the work presented here.

\subsubsection{Nadir reflectance}

Measurements of surface nadir reflectance (reflectivity) were carried out using a Dual Field of View (DFoV) nadir reflectance method (Duggin and Philipson, 1982). Two GER1500 spectroradiometers were placed on tripods viewing vertically downwards, with one measuring upwelling radiance from the snow surface and the second spectroradiometer simultaneously measuring the upwelling radiance from a white spectralon plate of known and carefully calibrated reflectance (i.e. a reference panel). Reflectance measurements were normally the average of a short transect of measurements, i.e. 10 measurements over a $5 \mathrm{~m}$ target of uniform snowpack. Albedo and reflectance of snowpack is solar zenith angle dependent (Grenfell et al., 1994; Munneke et al., 2008), thus measurements were taken near to the solar noon to minimise the solar zenith angle dependence. Reflectivity measurements were usually completed within $30 \mathrm{~min}$. The two GER1500 spectroradiometers were cross-calibrated in the field by simultaneously measuring the reflectance of the spectralon plate multiple times. Using a $3^{\circ}$ fore optic, the viewing footprint of the spectroradiometers measured $8 \mathrm{~cm}$ diameter on the measured surface. The spectroradiometers and spectralon plate are maintained and calibrated by the UK NERC Field Spectroscopy Facility.

The technique to determine scattering and absorption coefficients requires a measurement of the reflectivity and the $e$-folding depth of each layer. For the non-outcropping layers the overlying snowpack was carefully removed with a clean aluminium shovel. An area approximately $3 \mathrm{~m} \times 3 \mathrm{~m}$ was cleared.

Measurements were also made of snowpack stratigraphy (Fierz et al., 2009), temperature depth profile and snow den- sity with depth (using a $200 \mathrm{~cm}^{3}$ cutting box, similar to a version tested in Conger and McClung, 2009).

\subsection{Determining snowpack optical coefficients of scattering and absorption}

Using the TUV-snow radiative-transfer model (Lee-Taylor and Madronich, 2002) a wavelength dependent absorption cross-section due to light-absorbing impurities in the snow, $\sigma_{\mathrm{abs}}^{+}$, and scattering cross-section, $\sigma_{\text {scatt }}$, due to snow were determined from the field measurements of $e$-folding depth, reflectivity and snowpack density for each layer. The absorption and scattering cross-sections are constructed from wavelength specific determinations of absorption and scattering coefficients from $350-550 \mathrm{~nm}$. The TUV-snow radiativetransfer model has been used successfully to determine values of snowpack optical coefficients, $\sigma_{\text {abs }}^{+}$and $\sigma_{\text {scatt }}$, from field measurements from previous campaigns (Lee-Taylor and Madronich, 2002; Fisher et al., 2005; King et al., 2005; Beine et al., 2006; France et al., 2010). The TUV model has been validated using chemical actinometry with laboratory snow (Phillips and Simpson, 2005). A detailed description of the procedure to determine the scattering and absorption coefficients from $e$-folding depth and nadir reflectance is given by Lee-Taylor and Madronich (2002), but a brief summary is given here. Irradiances at different depths in snow are calculated using a range of values of $\sigma_{\text {scatt }}$ and $\sigma_{\text {abs }}^{+}$. Values of asymptotic $e$-folding depth and surface reflectance are calculated from these irradiances. The values of $\sigma_{\text {scatt }}$ and $\sigma_{\text {abs }}^{+}$are interpolated until a unique match between the field measured $e$-folding depth and reflectance with modelled $e$-folding depth and reflectance is found. The TUVsnow model (Lee-Taylor and Madronich, 2002) is a DISORT (Stamnes et al., 1988) coupled atmosphere-snow model running 8 streams with a pseudo-spherical correction. There are 71 atmospheric depths (spaced at $1 \mathrm{~m}$ for the first $10 \mathrm{~m}$ above the snow, $10 \mathrm{~m}$ intervals until $100 \mathrm{~m}, 100 \mathrm{~m}$ intervals up to $1 \mathrm{~km}, 1 \mathrm{~km}$ intervals up to $10 \mathrm{~km}$ and $2 \mathrm{~km}$ intervals up to $80 \mathrm{~km}$ ), 106 snowpack depths (with $1 \mathrm{~mm}$ spacing in the top $0.5 \mathrm{~cm}$ and $1 \mathrm{~cm}$ spacing for the rest of the $1 \mathrm{~m}$ of snowpack), clear sky conditions, no overhead aerosol, an earthsun distance based upon 1 January 2010, under snow albedo of 0.95 , an asymmetry factor of 0.89 , a solar zenith angle to correspond to measurements of reflectivity and an overhead column ozone of 300 Dobson Units (Ozone determined from measurements by the Ozone Monitoring Instrument, values during the season range from 260-340 DU, (McPeters et al., 1998)). Using TUV-snow to determine the effect of ozone column variation on nitrate photolysis, an increase in ozone from 260 to 340 DU results in a $14 \%$ decrease in the nitrate photolysis rate coefficient at the snowpack surface.

The method produces a unique solution for $\sigma_{\text {scatt }}$ and $\sigma_{\text {abs }}^{+}$ that satisfy both the measured reflectivity and $e$-folding depth for a specified wavelength. Values of $\sigma_{\text {scatt }}$ and $\sigma_{\text {abs }}^{+}$are determined for wavelengths $350-550 \mathrm{~nm}$ at $25 \mathrm{~nm}$ intervals. 


\subsection{Snowpack chemical measurements}

Measurements of depth-resolved nitrate concentrations in snow at the Dome $\mathrm{C}$ station were co-located with the main area of snowpack $e$-folding depth measurements $\left(75.1047^{\circ} \mathrm{S}, 123.3390^{\circ} \mathrm{E}\right)$. A $30 \mathrm{~cm}$ snow pit was sampled using $50 \mathrm{ml}$ Greiner PP centrifuge tubes that were previously rinsed with MilliQ quality water. Snow was collected every centimetre for the top $20 \mathrm{~cm}$ of the snowpack and one additional sample was taken at $30 \mathrm{~cm}$ depth. Nitrate concentrations were determined by a colorimetric method using a continuous flow analysis system in the field (Frey et al., 2009). The precision of this method is better than $3 \%$ in the concentration range of nitrate of 10 to $1000 \mathrm{ng} \mathrm{g}^{-1}$.

\subsection{Modelling in-snow nitrate photochemistry}

Nitrate photolysis rate coefficients, $\mathrm{N}_{\mathrm{NO}_{3}^{-}}$, for reaction (R1a), are calculated as shown in Eq. (2).

$J_{\mathrm{NO}_{3}^{-}}=\int_{\lambda_{1}}^{\lambda_{2}} \sigma(\lambda, T) \Phi(\lambda, T) I(\lambda, \theta, z) d \lambda$

Where $\sigma$ is the absorption cross-section of nitrate, $\lambda$ is the wavelength, $T$ is the temperature, $z$ is the depth into the snowpack, $I$ is the spherical irradiance ("actinic flux") within the snowpack, $\theta$ is the solar zenith angle and $\Phi$ is the quantum yield for nitrate photolysis.

The temperature-dependant quantum yield of Reaction (R1a) on ice and the absorption cross-section of nitrate in aqueous solution are both taken from Chu and Anastasio (2003). The quantum yield reported in Chu and Anastasio (2003) broadly agrees with the work of Dubowski et al. (2002) and is considered a good phenomological representation of the photolysis of nitrate in snow and ice. Other available quantum yield data for $308 \mathrm{~nm}$ photolysis of nitric acid on ice films of $0.92 \pm 0.26$ (Zhu et al., 2010) seem extremely high compared with previous data (Warneck and Wurzinger, 1988; Zellner et al., 1990; Dubowski et al., 2002; Chu and Anastasio, 2003), but if correct would potentially increase the $\mathrm{NO}_{2}$ production by a factor of $\sim 400$.

Photolysis rate coefficients for Reaction (R1a) are calculated at 126 depths (with extra $1 \mathrm{~mm}$ thick layers $0.5 \mathrm{~cm}$ each side of snow stratigraphic boundaries added to the layer spacing used to determine absorption and scattering coefficients within single snow units) within a $1 \mathrm{~m}$ semi-infinite snowpack. The optical coefficients (determined for a wavelength of $350 \mathrm{~nm}$ ), snowpack layer thicknesses, snowpack densities and snow temperatures as described in Table 1 are used. Values in Table 1 are from the results of this paper, however, reference is made to these values now for overall clarity of the methods used. The values of $\sigma_{\text {scatt }}$ and $\sigma_{\text {abs }}^{+}$at a wavelength of $350 \mathrm{~nm}$ are used for the calculation of the photochemical rate coefficients as the maximum in the action spectrum of nitrate photolysis is $\sim 320 \mathrm{~nm}$ (Chu and Anastasio, 2003).
A depth-integrated production rate of $\mathrm{NO}_{2}$ from the snowpack, $F\left(\mathrm{NO}_{2}\right)$, as a function of solar zenith angle, is calculated from $J_{\mathrm{NO}_{3}^{-}}$as shown in (3), and the value of $J_{\mathrm{NO}_{3}^{-}}$for (2) is calculated as a function of solar zenith angle and depth.

$F\left(\mathrm{NO}_{2}\right)=\int_{z=0 \mathrm{~m}}^{z=1 \mathrm{~m}}\left[\mathrm{NO}_{3}^{-}\right] J_{\mathrm{NO}_{3}^{-}} d z$

where $z$ is the depth into the snowpack, $\left[\mathrm{NO}_{3}^{-}\right]$is the concentration of nitrate (molecules per unit volume of snow), $J_{\mathrm{NO}_{3}^{-}}$ is the photolysis rate constant as a function of solar zenith angle and depth.

The depth-integrated production rate equates to a potential maximum molecular flux of $\mathrm{NO}_{2}$ exiting the snowpack assuming all of the $\mathrm{NO}_{2}$ produced by photolysis escapes the snowpack and does not undergo any secondary chemistry.

\section{Results}

The results are presented in three sections, the field data, determination of optical coefficients from the Dome C snowpack, and the calculation of depth-integrated production rates of $\mathrm{NO}_{2}$ due to in-snow nitrate photochemistry.

\subsection{Field results}

The measurements of snowpack stratigraphy, temperature, and density are shown in Fig. 1. The description of the typical stratigraphy in Table 1 is generalised from 14 snowpits dug around the Dome $\mathrm{C}$ base with comparable snowpack stratigraphy seen in each snowpit, four examples of real snowpack stratigraphy measurements are shown in Fig. 1a. The stratigraphy is comparable with other previously reported stratigraphy for Dome C (Warren et al., 2006; Fierz et al., 2009; Gallet et al., 2011). The general stratigraphy at Dome $\mathrm{C}$ is two windpack layers overlaying a hoar layer, formed through temperature gradient snow metamorphism (Gallet et al., 2011). The temperature-depth profile in Fig. 1b shows that snowpack temperature decreases $\sim 10^{\circ} \mathrm{C}$ with $60 \mathrm{~cm}$ of snow depth. Snowpack nitrate concentration-depth profiles for Dome $\mathrm{C}$ snowpits measured during the campaign are shown in Fig. 2.

The median $e$-folding depths measured for the three snowpack layers from different snowpit layers are shown in Fig. 1d, along with the corresponding nadir reflectivity measurements for the same snowpack layer in Fig. 1c. The reflectivity of snowpack matching the median $e$-folding depth is used for all calculations. The maximum $e$-folding depth occurs between $400 \mathrm{~nm}$ and $450 \mathrm{~nm}$ in the hoar layer and in the windpacked layers. The reflectivity data shows that the maximum reflectance occurs between $450 \mathrm{~nm}$ and $500 \mathrm{~nm}$ for each of the snowpack layers. A similar pattern of reflectance and light attenuation maxima is also considered in Warren et 

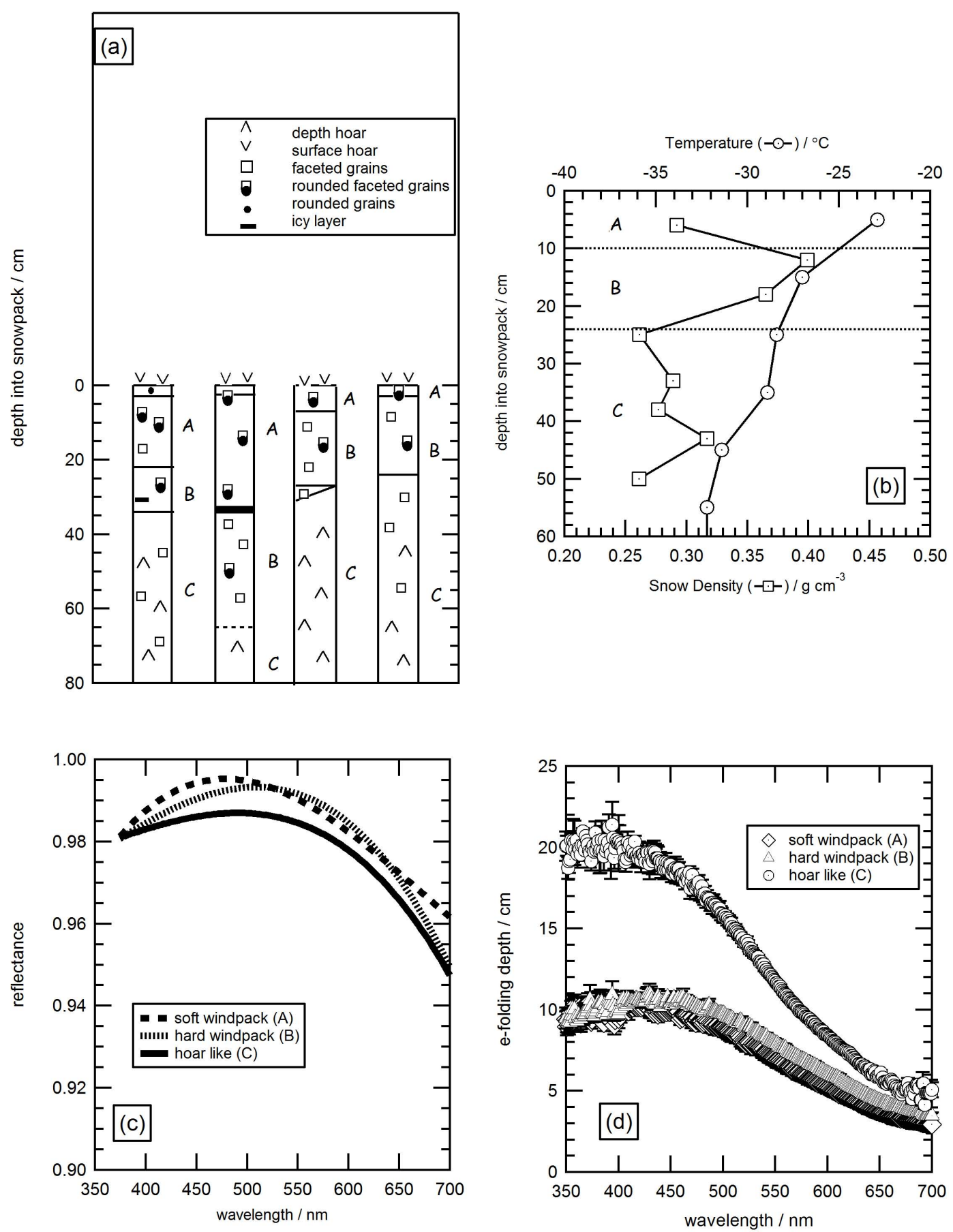

Fig. 1. (a) Snowpack stratigraphy measurements from four snowpacks at/near Dome C between 19 December 2009 and 13 January 2010 to demonstrate the uniformity of the snowpack in the area, symbols used from the International classification of snow on the ground (Fierz et al., 2009). Layers are summarised into A, B and C as referred to in the text and tables in the rest of the paper as soft windpack (A), hard windpack (B) and hoar-like (C). The average snowpack stratigraphy as measured is shown in Table 1. (b) Measured snowpack temperature and density profiles for the snow layers from the snowpack measured on 6 January 2010, a typical snowpack stratigraphy for the sampled region. Temperatures measured at local noon. (c) Nadir reflectivity versus wavelength measured for each of the snowpack layers corresponding to the $e$-folding depth measurements in Fig. 1d, 2 standard deviation errors are typically $1.5 \%$ from the mean and are omitted for clarity. (d) Comparison of median $e$-folding depths versus wavelength for each of the snowpack layers, error bars are 2 standard deviation from the median $e$-folding value. 
Table 1. Snowpack properties for each snowpack layer at Dome C.

\begin{tabular}{lccrrrr}
\hline $\begin{array}{l}\text { snow } \\
\text { description }\end{array}$ & $\begin{array}{c}\sigma_{\text {scatt }} / \\
\mathrm{m}^{2} \mathrm{~kg}^{-1} \\
(\lambda=350 \mathrm{~nm})\end{array}$ & $\begin{array}{c}\sigma_{\text {abs }}^{+} / \\
\mathrm{cm}^{2} \mathrm{~kg}^{-1} \\
(\lambda=350 \mathrm{~nm})\end{array}$ & $\begin{array}{r}\text { snowpack } \\
\text { temperature/ }{ }^{\circ} \mathrm{C}\end{array}$ & $\begin{array}{r}\text { density/ } \\
\mathrm{g} \mathrm{cm}^{3}\end{array}$ & $\begin{array}{r}\text { snowpack } \\
\text { layer } \\
\text { thickness/cm }\end{array}$ & $\begin{array}{r}\text { grain size } \\
/ \mathrm{mm}\end{array}$ \\
\hline Soft windpack & $14-22(20)$ & $1.3-2.2(1.7)$ & -23 & 0.3 & 11 & $0.3-1$ \\
Hard windpack & $17-24(19)$ & $1.3-1.8(1.7)$ & -27 & 0.38 & 21 & $0.3-2$ \\
Hoar like layer & $8-16(10)$ & $0.6-1.4(1.2)$ & -30 & 0.28 & 68 & $1-4$ \\
\hline
\end{tabular}

Values in brackets are the median values of the derived optical coefficients and are the values used to model the snowpack photochemical production. Snow temperature and density are taken from the snowpack measured on the 6 January which is representative of our modelled snowpack.

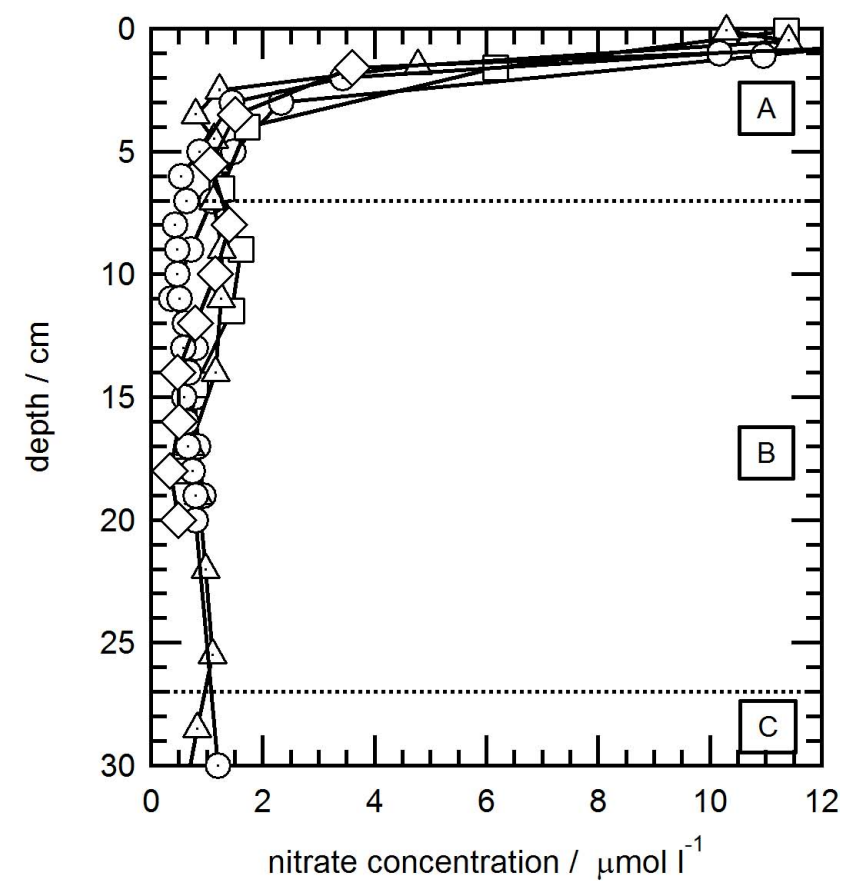

Fig. 2. Measured snowpack nitrate concentrations at Dome $C$ from two sites during December 2009 to January 2010. Dashed lines are the depths where the stratigraphy changes within a typical snowpack profile demonstrating the uniformity of nitrate profile within the snow cover at Dome $\mathrm{C}$. The dotted circles represent the nitrate profile used in the calculation of $\mathrm{NO}_{2}$ flux measurements as it was measured at the site of the majority of snowpack $e$-folding depth and reflectivity measurements.

al. (2006) and explained through the presence of snowpack impurities with wavelength dependent absorptions.

\subsection{Snowpack Optical coefficients}

Values of the optical coefficients ( $\sigma_{\text {scatt }}$ and $\sigma_{\text {abs }}^{+}$) are reported for wavelengths of $350 \mathrm{~nm}$ (Table 1) and $400 \mathrm{~nm}$ (Table 2). Data in Table 1 are used for the calculation of $J_{\mathrm{NO}_{3}^{-}}$and data in Table 2 are to allow comparisons of Dome $\mathrm{C}$ snowpack optical coefficients to other snowpack measurements.
The absorption of light in the snowpack is due to absorption by water ice (weak absorption in the visible) and impurities in the snowpack. Plotting the absorption cross-section for light absorbing impurities, $\sigma_{\text {abs }}^{+}$, versus wavelength, in Fig. 3 demonstrates the absorption in the snowpack owing to impurities. It was thought that absorption is dominated by the presence of black carbon (Lee-Taylor and Madronich, 2002). However, the variation of $\sigma_{\mathrm{abs}}^{+}$with wavelength, as shown in Fig. 3, decreases with increasing wavelength and matches a scaled linear combination of the absorption spectrum of HULIS (Hoffer et al., 2006) and black carbon (the absorption cross-section of black carbon is calculated using Mie theory from the black carbon proxy in Warren and Wiscombe, 1985). The implication is that the impurities at Dome $\mathrm{C}$ are due to atmospheric deposition of HULIS, and black carbon, rather than primarily black carbon. The absorption due to black carbon is relatively invariant with wavelength across UV-visible wavelengths. By fitting scaled black carbon and HULIS absorption cross-section to the absorption cross-section of light absorbing impurities in snow (a similar method is applied in Doherty et al., 2010), then the amount of black carbon in the snow at Dome $\mathrm{C}$ varies between 1 and $5 \mathrm{ng} \mathrm{g}^{-1}$, similar to the $3.3 \mathrm{ppb}$ measured in the surface snow in 2004 at Dome C by Warren et al. (2006). The value of $\sigma_{\text {scatt }}$ is generally invariant with wavelength over $350-550 \mathrm{~nm}$. The range of black carbon concentration is $\sim 0 \mathrm{ng} \mathrm{g}^{-1}$ and $13 \mathrm{ng} \mathrm{g}^{-1}$ if the measurement uncertainty in the reflectivity measurement of $2 \sigma$ is propagated through to the black carbon concentrations.

\subsection{Dome $\mathrm{C}$ in-snow nitrate photolysis rate coefficients}

The photolysis rate coefficients for reaction (R1a) calculated at each of the 126 depths within the snowpack for nitrate photolysis are shown as isopleths of equal $J_{\mathrm{NO}_{3}^{-}}$versus depth and solar zenith angle in Fig. 4. Figure 4 highlights two points: the variation of $J_{\mathrm{NO}_{3}^{-}}$with solar zenith angle and depth between the two windpacked layers is very small, thus validating previous studies where Antarctic windpacked snows were treated as a bulk snowpack despite small changes in stratigraphy (Beine et al., 2006). Secondly, the change 
Table 2. Comparison of optical coefficients for Dome C snow layers with previously investigated sites, all optical coefficient measurements are for a wavelength of $400 \mathrm{~nm}$.

\begin{tabular}{|c|c|c|c|c|c|c|}
\hline \multirow[t]{2}{*}{ Study } & \multirow[t]{2}{*}{ Snow description } & \multicolumn{2}{|c|}{ Measurements? } & \multirow{2}{*}{$\begin{array}{r}\sigma_{\text {scatt }} / \\
\mathrm{m}^{2} \mathrm{~kg}^{-1}\end{array}$} & \multirow{2}{*}{$\begin{array}{r}\sigma_{\mathrm{abs}}^{+} / \\
\mathrm{cm}^{2} \mathrm{~kg}^{-1}\end{array}$} & \multirow[b]{2}{*}{ notes } \\
\hline & & $e$-fold & reflectivity & & & \\
\hline \multirow[t]{2}{*}{ Grenfell and Maykut (1977) } & Arctic summer dry & $\checkmark$ & $\checkmark$ & 6.4 & 7.3 & \\
\hline & Arctic summer melting & $\checkmark$ & $\checkmark$ & 1.1 & 7.8 & \\
\hline Grenfell et al. (1994) & Antarctic South Pole & $\checkmark$ & $\checkmark$ & $6-25$ & 0 & \\
\hline King and Simpson (2001) & Arctic spring windblown & $\checkmark$ & $\times$ & $6-30$ & $4-5$ & \\
\hline Beaglehole et al. (1998) & Antarctic summer coastal & $\checkmark$ & $x$ & $7-13$ & 0.4 & snow not measured in-situ \\
\hline \multirow[t]{4}{*}{ Beine et al. (2006) } & Antarctic coastal hard windpack & $\checkmark$ & $\checkmark$ & 1.3 & 4.3 & \\
\hline & Antarctic coastal soft windpack & $\checkmark$ & $\checkmark$ & 6.3 & 24 & \\
\hline & Antarctic coastal recent windblown & $\checkmark$ & $\checkmark$ & 3.7 & 37 & \\
\hline & Antarctic coastal precipitation & $\checkmark$ & $\checkmark$ & 4.3 & 17 & \\
\hline \multirow[t]{2}{*}{ France et al. (2010) } & Fresh Ny-Ålesund snowpack & $\checkmark$ & $\checkmark$ & 16.7 & 2.7 & \\
\hline & Melting Ny-Ålesund snowpack & $\checkmark$ & $\checkmark$ & 0.8 & 19.8 & \\
\hline \multirow[t]{4}{*}{ France et al. (2011) } & Ny-Ålesund - old windpack & $\checkmark$ & $\checkmark$ & 9.5 & 1.4 & \\
\hline & Ny-Ålesund - fresh windpack & $\checkmark$ & $\checkmark$ & 7.7 & 5.3 & \\
\hline & Ny-Ålesund - marine influenced & $\checkmark$ & $\checkmark$ & 20 & 3.4 & \\
\hline & Ny-Ålesund - glacial & $\checkmark$ & $\checkmark$ & 25.5 & 0.5 & \\
\hline \multirow[t]{3}{*}{ This Work } & Dome $\mathrm{C}$ - soft windpack & $\checkmark$ & $\checkmark$ & $20-42$ & $0.5-1.1$ & \\
\hline & Dome C - hard windpack & $\checkmark$ & $\checkmark$ & $18-40$ & $0.2-1.4$ & \\
\hline & Dome C - hoar like layer & $\checkmark$ & $\checkmark$ & $9-18$ & $0.5-1.8$ & \\
\hline
\end{tabular}

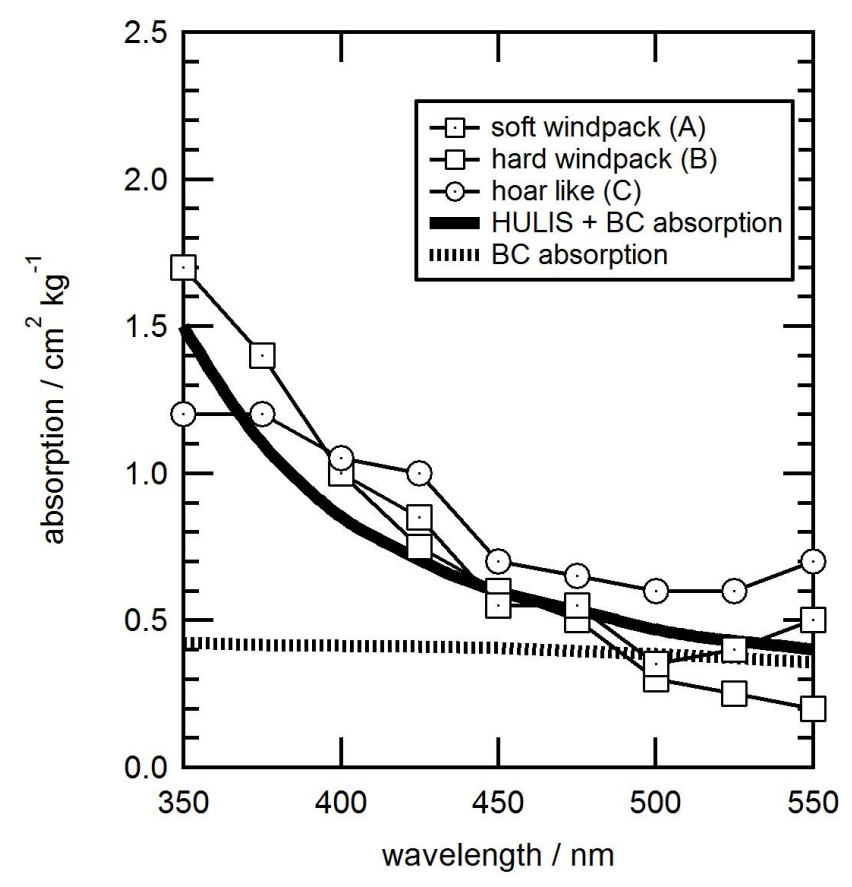

Fig. 3. Absorption, $\sigma_{\text {abs }}^{+}$, versus wavelength for impurities in the snowpack layers. The absorption due to impurities can be fitted to a linear combination of absorption cross-sections due to HULIS (Hoffer et al., 2006) and black carbon (see text). The linear combination of absorption cross-sections for HULIS and black carbon in the figure is illustrative and not fitted to a specific snowpack layer. in variation of photolysis rate coefficient, $J_{\mathrm{NO}_{3}^{-}}$, with solar zenith angle and depth for the hoar-like layer is extremely pronounced and shows that the use of a multi-layer snowpack model should be considered where optical properties are very different between layers.

\section{$3.4 \mathrm{NO}_{2}$ fluxes}

The potential molecular flux of $\mathrm{NO}_{2}$ (disregarding matrix cage effects, diffusion, chemical conversion prior to emission and forced ventilation from the snowpack) from the snowpack owing to nitrate photolysis within the snowpack versus solar zenith angle is shown in Fig. 5 and calculated using the nitrate profile shown in Fig. 2 and Eq. (3). Figure 5 is calculated for clear sky conditions and assumes all photoproduced $\mathrm{NO}_{2}$ is released from the snowpack. Figure 5 allows a simple comparison with previous or future measurements of $\mathrm{NO}_{\mathrm{x}}$ fluxes at Antarctic sites.

\section{Discussion}

The discussion is split into 4 sections:

1. A comparison of field measurements of snowpack irradiance and snow stratigrapghy with previous snowpacks measurements at Dome $\mathrm{C}$ and analysis of the variation of the optical coefficients with wavelength.

2. A discussion of the value of the optical coefficients $\left(\sigma_{\text {scatt }}\right.$ and $\left.\sigma_{\text {abs }}^{+}\right)$, with comparison to previously 


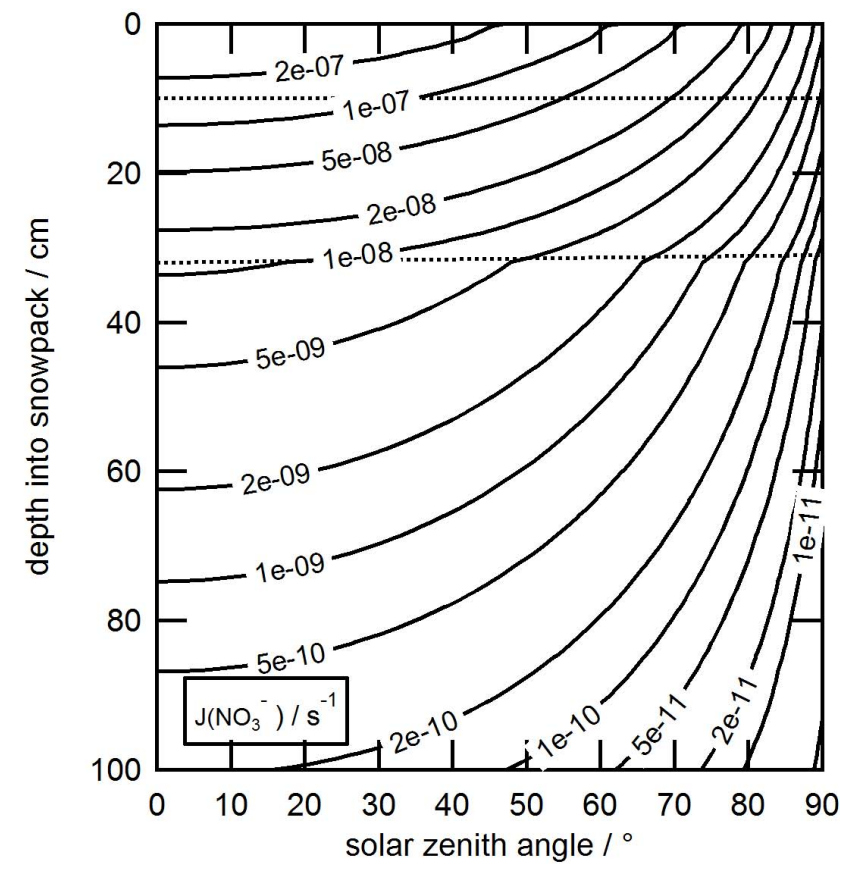

Fig. 4. Nitrate photolysis rate coefficient contours for a Dome $\mathrm{C}$ snowpack (as described in Table 1), plotted against solar zenith angle and depth into the snowpack. Horizontal dashed lines represent the depths at which the snowpack stratigraphy changes.

determined values of $\sigma_{\text {scatt }}$ and $\sigma_{\text {abs }}^{+}$, and a discussion of variation between snowpack layers at Dome $\mathrm{C}$.

3. An overview of the calculated values of the photolysis rate coefficient, within the snowpack and the depthintegrated production rates of $\mathrm{NO}_{2}$.

4. A comparison of the calculated depth-integrated production rates of $\mathrm{NO}_{2}$ at Dome $\mathrm{C}$ with the work of Wolff et al. (2002) and the impact of photochemistry on the preservation of nitrate with depth into the snowpack.

\subsection{Comparison of field measurements}

The stratigraphy of Dome C snowpack is relatively constant within the vicinity of the base $(<5 \mathrm{~km})$, with thicknesses of the snowpack layers varying from $0 \mathrm{~cm}$ to $35 \mathrm{~cm}$ for the soft windpack (Layer A) and $5 \mathrm{~cm}$ to $65 \mathrm{~cm}$ for the hard windpack (Layer B). The hoar like layer (Layer C) was ubiquitous at Dome $\mathrm{C}$ below the windpack and was greater than $50 \mathrm{~cm}$ thick at each site visited. Minor layers such as $1 \mathrm{~mm}$ thick icy layers were noted in the detailed stratigraphy as shown in Fig. 1, but were not present at every site and were too thin to determine an $e$-folding depth. Given the repeatability of $e$-folding depth measurements within layers suggests that the thin icy layers do not have a measurable effect on the $e$-folding depth. Figure 4 also demonstrates that the calculation of the photolysis rate coefficient, $\mathrm{J}_{\mathrm{NO}_{3}^{-}}$, is not sensitive to the relative amounts of soft or hard windpack. The major change in the photolysis rate coefficient, $J_{\mathrm{NO}_{3}^{-}}$, occurs with the transition from windpack to the hoar-like layer.

The $e$-folding depths measured show there are two main optical layers, a windpack layer, either soft or hard, which have asymptotic $e$-folding depths of $\sim 10 \mathrm{~cm}$ at a wavelength of $400 \mathrm{~nm}$ and a depth-hoar like layer which has an asymptotic $e$-folding depth of $\sim 20 \mathrm{~cm}$ at a wavelength of $400 \mathrm{~nm}$. The combined thickness of the windpack layers is typically $20-35 \mathrm{~cm}$. As previously determined, $85 \%$ of the photolysis occurring in snowpack occurs in the top two $e$ folding depths (King and Simpson, 2001), so at Dome C, at least $85 \%$ of the photolysis occurs in the windpacked layers. However, it is worth noting that up to $15 \%$ of the photolysis could be occurring in the hoar like layer. The processes of photochemistry and photolysis occurring in hoar like layers (to our knowledge) have not been investigated. The measured $e$-folding depths are a factor of 3 longer than the $3.7 \mathrm{~cm}$ at a wavelength of $320 \mathrm{~nm}$ previously used by Wolff et al. (2002). The $e$-folding depth for layer C $(\sim 20 \mathrm{~cm}$ and a wavelength of $400 \mathrm{~nm}$ ) is similar to the $e$-folding depth measured in snowpack at depths between 40 and $90 \mathrm{~cm}$ for wavelengths between $380 \mathrm{~nm}$ and $450 \mathrm{~nm}$, as investigated in Warren et al. (2006). The $e$-folding depth of $\sim 3 \mathrm{~m}$ at $380 \mathrm{~nm}$ for a snow depth of $90-135 \mathrm{~cm}$ measured in Warren et al. (2006) is far larger than any measurements of $e$ folding depth made in the top $50 \mathrm{~cm}$ of snowpack during this work. However, snowpack at depths deeper than $3 e$-folding depths $(\sim 40 \mathrm{~cm})$ do not significantly affect calculations of current depth-integrated production of $\mathrm{NO}_{2}$ from nitrate photolysis. The deeper snowpack layers $(90-135 \mathrm{~cm})$ as studied by Warren et al. (2006) are highly transmittive due to the very low black carbon concentrations (corresponding to snow that fell before to Concordia station was built) in the snow and also due to snow metamorphism reducing $\sigma_{\text {scatt }}$ in these deeper layers. It was not possible with the equipment available to determine $e$-folding depths for the snowpack deeper than $50 \mathrm{~cm}$ depth, and therefore it is not possible to determine whether the presence of the base has had an effect on the snowpack $e$-folding depth for the snow currently at 90$135 \mathrm{~cm}$ depth to compare directly with Warren et al. (2006). Snow grain sizes previously measured in Antarctica report typical grain sizes of $\sim 0.2 \mathrm{~mm}$ (Gay et al., 2002) using high resolution imaging of surface snow and $0.8-1.8 \mathrm{~mm}$ for the EAIS measured by satellite retrieval (Scambos et al., 2007). The grain sizes measured by hand lens during this study for the top $20 \mathrm{~cm}$ of snow at Dome C are $0.3-2 \mathrm{~mm}$ (Table 1).

\subsection{Optical coefficients of Dome C snowpack}

The absorption cross-sections for the snowpack impurities in the three snowpack layers in Fig. 3 show an increased absorption in the UV region compared to minimum absorption occurring at a wavelength around $500 \mathrm{~nm}$. A black carbon impurity would absorb almost uniformly across the wavelength 
range 350-550 $\mathrm{nm}$. Increasing absorption with decreasing wavelength over the wavelength range $350-550 \mathrm{~nm}$ indicates the presence of UV absorbing compounds in the snowpack such as humic material or HULIS (HUmic LIke Substances), albeit in very small concentrations. Previous measurements of black carbon in the Dome $\mathrm{C}$ surface snowpack made in 2004 measured $3.3 \mathrm{ng} \mathrm{g}^{-1}$ of black carbon and $26 \mathrm{ng} \mathrm{g}^{-1}$ of dust (Warren et al., 2006). The plot of absorption crosssection in Fig. 2 can be fitted to an absorption cross-section of black carbon and an absorption cross-section for biomass burning derived HULIS. The black carbon absorption crosssection is based on a Mie calculation of Warren and Wiscombe (1980) assuming spherical black carbon particles in the snow of $0.1 \mu \mathrm{m}$ radius, $1 \mathrm{~g} \mathrm{~cm}^{-3}$ density and a refractive index of 1.8-0.5i. The HULIS absorption cross-section is taken from Hoffer et al. (2006). The linear combination of black carbon and HULIS absorption cross-sections allow an estimate of black carbon and HULIS concentrations in snowpack. The concentrations of black carbon estimated for the surface snowpack layers is $1-2 \mathrm{ng} \mathrm{g}^{-1}$, comparable to the black carbon concentrations measured by Warren et al. (2006) for the same snowpack locality. Warren et al. (2006) measured $3.3 \mathrm{ng} \mathrm{g}^{-1}$ of black carbon for snowpack contaminated by emissions from the base, and 0.6$1.4 \mathrm{ng} \mathrm{g}^{-1}$ for snowpack formed before the presence of the base at Dome C.

The optical coefficients at a wavelength of $400 \mathrm{~nm}, \sigma_{\text {scatt }}$ and $\sigma_{\text {abs }}^{+}$, at Dome $\mathrm{C}$ are compared to previously determined values for other snowpacks in Table 2. The optical coefficients are reported for a wavelength of $400 \mathrm{~nm}$ to provide direct comparisons with previous literature. The absorption coefficient at a wavelength of $400 \mathrm{~nm}$ is small compared to other sites globally. In very clean snowpacks such as Central Antarctica, the albedo is close to unity. The determinations of absorption and scattering coefficients are sensitive to the albedo for clean snowpacks with large albedo (Lee-Taylor and Madronich, 2002).

\section{3 $\mathrm{NO}_{2}$ fluxes from the Dome $\mathrm{C}$ snowpack}

The depth-integrated production rates (potential molecular flux) of gaseous $\mathrm{NO}_{2}$ from the snowpack (Fig. 5) can be compared to fluxes of $\mathrm{NO}_{\mathrm{x}}$ estimated from measured NO fluxes from Antarctic plateau snow of $\sim 4 \times 10^{12}$ molecules $\mathrm{m}^{-2} \mathrm{~s}^{-1}\left(24 \mathrm{nmol} \mathrm{m}^{-2} \mathrm{~h}^{-1}\right)$ for a solar zenith angle around $68^{\circ}$ (Oncley et al., 2004). Modelled $\mathrm{NO}_{\mathrm{x}}$ flux data from the same campaign determined an average of 3.2-4.2 $\times 10^{12}$ molecules $\mathrm{m}^{-2} \mathrm{~s}^{-1}\left(19-25 \mathrm{nmol} \mathrm{m}^{-2} \mathrm{~h}^{-1}\right)$ (Wang et al., 2007). Coastal Antarctic fluxes of $\mathrm{NO}_{\mathrm{x}}$ from the snowpack were measured during early February, 2005 with mean daily fluxes of $1.7-3.4 \times 10^{12}$ molecules $\mathrm{m}^{-2} \mathrm{~s}^{-1}$ (10-20 $\mathrm{nmol} \mathrm{m}^{-2} \mathrm{~h}^{-1}$ ) (Bauguitte et al., 2009).

For Dome C, a flux of $\mathrm{NO}_{2}$ of 2.4$3.8 \times 10^{12}$ molecules $\mathrm{m}^{-2} \mathrm{~s}^{-1} \quad\left(14-23 \mathrm{nmol} \mathrm{m}^{-2} \mathrm{~h}^{-1}\right)$ for a solar zenith angle of $68^{\circ}$ (Fig. 5) is calculated, similar

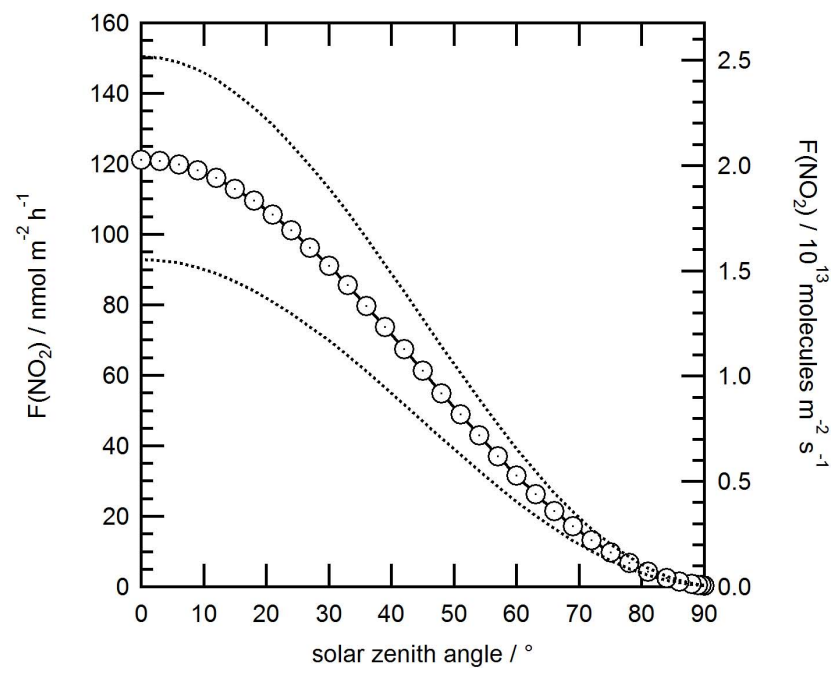

Fig. 5. Maximum potential flux of $\mathrm{NO}_{2}$ from the snowpack versus solar zenith angle, assuming all photoproduced $\mathrm{NO}_{2}$ from nitrate photolysis is liberated to the atmosphere. The snowpack stratigraphy is taken from Table 1 . The central line (dotted circles) is calculated using the dotted circled nitrate profile from Fig. 2. The dotted lines above and below represent minimum and maximum $\mathrm{NO}_{2}$ depth-integrated production rates calculated using the other measured nitrate profiles shown in Fig. 2.

in magnitude to the $\mathrm{NO}_{\mathrm{x}}$ flux estimated during the ISCAT (Investigation of Sulfur Chemistry in the Antarctic Troposphere) campaign at South Pole (Dibb et al., 2004). One source of uncertainty in estimating potential $\mathrm{NO}_{2}$ production rates are quantum yields of nitrate and nitric acid and their relative amounts in polar snow.

\subsection{Comparison with previous Antarctic plateau nitrate photolysis modelling}

Photolysis of nitrate in polar snow removes nitrate from the snowpack and provides a source of $\mathrm{NO}_{2}$ to the overlying atmosphere, resulting in smaller concentrations of nitrate with increasing depth in the snowpack (as seen in Fig. 2). Previous work estimating fluxes of $\mathrm{NO}_{2}$ and modelling nitrate loss with depth within the snowpack for a theoretical Antarctic snowpack (located at the South Pole) predicted a maximum $\mathrm{NO}_{2}$ flux of $1.4 \times 10^{12}$ molecules $\mathrm{m}^{-2} \mathrm{~s}^{-1}\left(8 \mathrm{nmol} \mathrm{m}^{-2} \mathrm{~h}^{-1}\right)$ from the snowpack. According to previous modelling, a maximum of $40 \%$ of the nitrate loss can be attributed to the photochemical depletion of nitrate within the snow (Wolff et al., 2002). However, the work of Wolff et al. (2002) assumed an $e$-folding depth of $3.7 \mathrm{~cm}$ and a snowpack stratigraphy uniform with depth. The work presented here demonstrates that these calculations may need updating. The following updates between this work and Wolff et al. (2002) were made: the absorption cross-section (measured in aqueous solution at $278^{\circ} \mathrm{K}$ ) and the quantum yield (measured on ice pellets) for nitrate photolysis is from Chu and Anastasio (2003) rather 


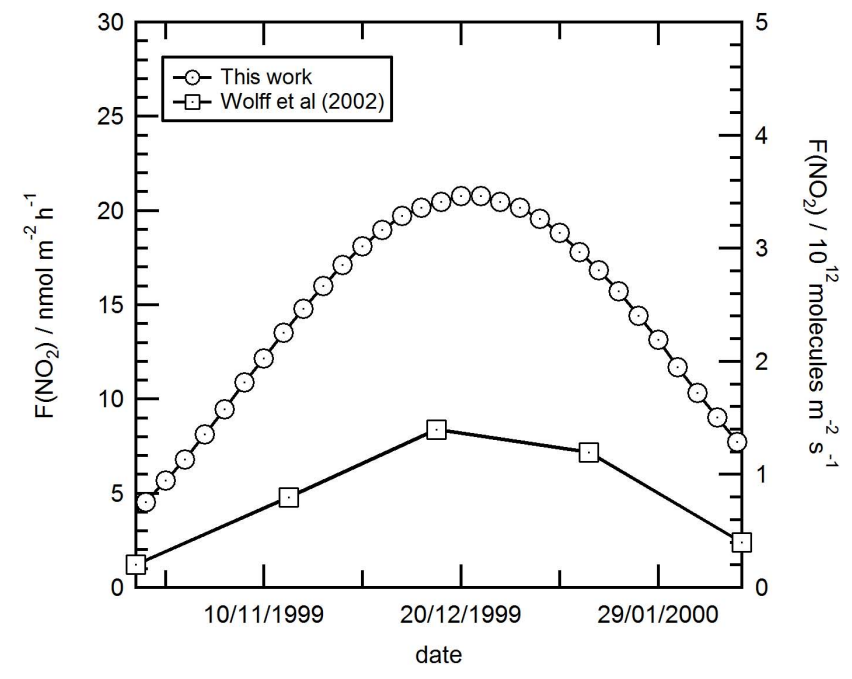

Fig. 6. Modelled depth-integrated production rates of $\mathrm{NO}_{2}$ from a South Pole site (assuming the snowpack properties are the same as Dome C) as a direct comparison with the work of Wolff et al. (2002). The depth-integrated production rates of $\mathrm{NO}_{2}$ (dotted circles) is calculated using the dotted circled nitrate profile from Fig. 2.

than Burley and Johnston (1992), and the ice absorption spectrum is taken from Warren (2008). The model snowpack is input in the 8-stream TUV-snow model (Lee-Taylor and Madronich, 2002) (vs. the 4-stream radiative-transfer model used in Wolff et al., 2002) using the measured optical coefficients (Table 1). The radiative-transfer model used in Wolff et al. (2002) was an in-house British Antarctic Survey model (Gardiner and Martin, 1997). For the calculation of $\mathrm{NO}_{2}$ fluxes from the snowpack, the nitrate concentration of $100 \mu \mathrm{mol} \mathrm{kg}^{-1}$ in the surface snow chosen in Wolff et al. (2002) is replaced with a measured nitrate profile shown in Fig. 2.

The comparison between the calculations of snowpack $\mathrm{NO}_{2}$ production rates of Wolff et al. (2002) and this work are shown in Fig. 6. The updated radiative-transfer modelling for a Dome C snowpack with layer thicknesses described in Table 1 at a South Pole location gave a factor of 3 increase in the $\mathrm{NO}_{2}$ production from Antarctic snowpack for the same solar zenith angles when compared to Wolff et al. (2002); a combined effect of the longer $e$-folding depth and using a measured in snow nitrate profile.

The second part of the work reported in Wolff et al. (2002) demonstrated that relative to that at depth, the maximum photolytic loss of nitrate in snow is only $40 \%$, with other processes such as re-evaporation or larger photolysis rate coefficients from nitric acid photolysis invoked to explain the rest of the measured nitrate profiles such as shown in Fig. 2. To test whether this is reproducible with $e$-folding depths and stratigraphy measurements reported here, data from Fig. 3, p5 in Wolff et al. (2002) is reproduced using the nitrate pho-

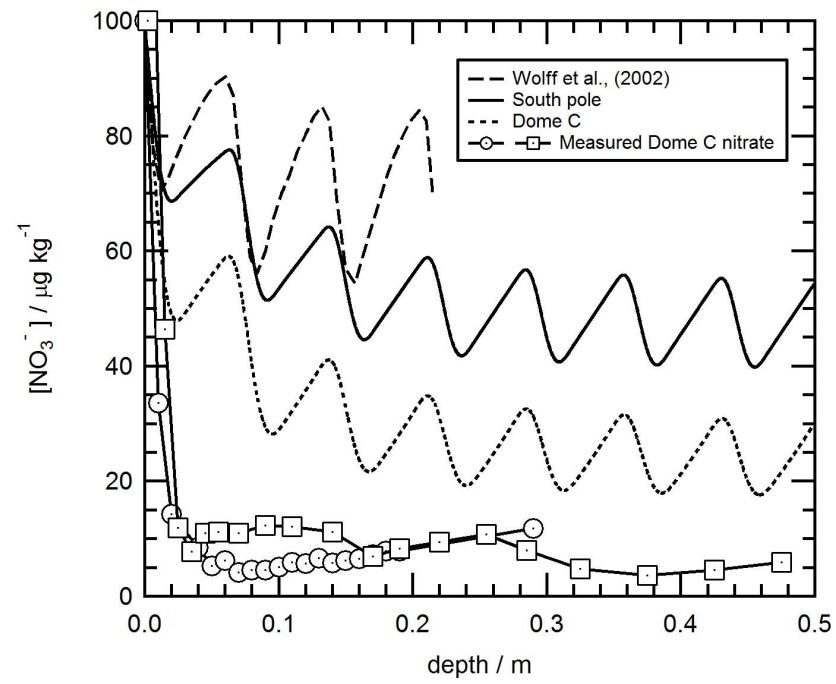

Fig. 7. Depletion of nitrate concentration with depth into the snowpack due to only photolysis, assuming clear skies at South Pole and clear skies at Dome $\mathrm{C}$, a Dome $\mathrm{C}$ accumulation rate $\left(72 \mathrm{~mm} \mathrm{yr}^{-1}\right)$ and a deposited nitrate concentration of $100 \mu \mathrm{g} \mathrm{kg}^{-1}$ continuously deposited year round. The nitrate concentration profile measured within the snowpack at Dome C was measured on 11 January 2010 and has been scaled to $100 \mu \mathrm{g} \mathrm{kg}^{-1}$ at the surface.

tolysis rate coefficients calculated in this work. The calculated photolysis rate constants for nitrate photolysis versus depth and solar zenith angle shown in Fig. 4 were used in a simple nitrate depletion model for snowpacks located at South Pole and Dome C. The initial snowpack nitrate concentration was assumed to be $100 \mu \mathrm{g} \mathrm{kg}^{-1}$ with a constant year round snow burial rate of $72 \mathrm{~mm} \mathrm{yr}^{-1}$. The model snowpack was split into layers $1 \mu \mathrm{m}$ thick and the loss of nitrate calculated in each layer on a daily basis. After each day, the snowpack was buried by $197 \mu \mathrm{m}$ and fresh snow $197 \mu \mathrm{m}$ deep containing $100 \mu \mathrm{g} \mathrm{kg}^{-1}$ of nitrate is deposited on the surface. The model is repeated for $10 \mathrm{yr}$ with solar zenith angles for both a South Pole locality and a Dome C locality. The depth profile of nitrate concentration, due to only photolytic loss, for a snowpit at a notional South Polar site and a Dome $\mathrm{C}$ site, calculated on a daily basis, is shown in Fig. 7, and is compared directly with the work of Wolff et al. (2002). The modelled photolytic loss is also compared to a measured nitrate concentration profile at Dome C, (scaled to $100 \mu \mathrm{g} \mathrm{kg}^{-1}$ at the surface) to determine if photochemical depletion can reproduce a typical measured nitrate profile at Dome C. The seasonal variation of nitrate concentration with depth in the modelled signal is not always preserved in measured profiles, (Fig. 2) as other post-depositional loss such as diffusion and re-evaporation processes may smooth the profile (Wagenbach et al., 1994).

For South Pole, the nitrate concentration in the snowpack can be reduced by $\sim 60 \%$ of the initial concentration by photolysis. For Dome C, the nitrate concentration can be reduced 
by $\sim 80 \%$ of the surface concentration. The rapidity of the nitrate loss at Dome $\mathrm{C}$ in the upper most part of the snowpack cannot be reproduced with a simplistic photochemical depletion model as above. The differences between modelled nitrate profiles for Dome $\mathrm{C}$ and South Pole depletion are due to the smaller solar zenith angles (i.e. the sun higher in sky) at Dome C compared to South Pole, leading to larger photolysis rate constants and more nitrate depletion for a constant burial rate. The differences between measured and modelled nitrate depth profiles could be due to a number of processes, the re-deposition of nitrate at the surface, enhancing the surface concentrations relative to at depth, the continued evaporation of nitrate from within the snowpack, or an increased photolytic reaction rate of nitrate within the snowpack compared to laboratory measured values of the quantum yield (e.g. Zhu et al., 2010).

\section{Conclusions}

At Dome $\mathrm{C}, 85 \%$ of the $\mathrm{NO}_{\mathrm{x}}$ production from the photolysis of nitrate occurs in the top $20 \mathrm{~cm}$ of snow cover, with the majority of the remaining $15 \%$ of the snowpack photochemistry occurring in hoar like layers. The $e$-folding depth in the windpacked snow layers is $\sim 10 \mathrm{~cm}$ at a wavelength of $400 \mathrm{~nm}$ and $\sim 20 \mathrm{~cm}$ at a wavelength of $400 \mathrm{~nm}$ in the hoarlike snow layer beneath the windpacks. This is the first time a radiative-transfer model has been used to determine photolysis rates in Antarctic Plateau snowpack with different optical properties in each layer and is worthwhile for considering changes in stratigraphy between windpack and hoar-like snow, but is not worth the extra computation effort to distinguish between soft and hard windpack.

The absorption spectrum of light absorbing impurities in the Dome C snowpack as shown by the variation of $\sigma_{\text {abs }}^{+}$versus wavelength is consistent with HULIS and black carbon particles in the snowpack. The black carbon concentration in Dome $\mathrm{C}$ snowpack is estimated at $1-5 \mathrm{ng} \mathrm{g}^{-1}$.

The calculated depth-integrated production rates of $\mathrm{NO}_{2}$ from nitrate photochemistry in the snowpack on the Antarctic plateau at Dome $\mathrm{C}$ is of similar magnitude to fluxes of $\mathrm{NO}_{\mathrm{x}}$ measured and modelled for a previous Antarctic campaign at the South Pole for equivalent solar zenith angles, with depth-integrated production rates of $\mathrm{NO}_{2}$ of $5.3 \times 10^{12}$ molecules $\mathrm{m}^{-2} \mathrm{~s}^{-1}$, $2.3 \times 10^{12}$ molecules $\mathrm{m}^{-2} \mathrm{~s}^{-1}$ and $8 \times 10^{11}$ molecules $\mathrm{m}^{-2} \mathrm{~s}^{-1}\left(32 \mathrm{nmol} \mathrm{m}^{-2} \mathrm{~h}^{-1}, \quad 14 \mathrm{nmol} \mathrm{m}^{-2} \mathrm{~h}^{-1}\right.$ and $5 \mathrm{nmol} \mathrm{m}^{-2} \mathrm{~h}^{-1}$ ) calculated for solar zenith angles of $60^{\circ}, 70^{\circ}$ and $80^{\circ}$ respectively for clear sky conditions at Dome C. Using the $e$-folding depths measured at Dome C, photochemistry of nitrate can only account for a maximum of $60 \%$ reduction of nitrate concentration with depth in the snowpack at a notional South Polar site and $\sim 80 \%$ of the reduction of nitrate concentration at Dome C. Constraining the amount of nitrate depletion in snowpack at important ice-core drilling sites, such as Dome C, is an important step in beginning to understand the causes of isotopic shifts seen in nitrate records in snow and ice cores (Rothlisberger et al., 2000; Frey et al., 2009).

A simple photochemical model cannot re-produce nitrate concentration profiles seen in the snowpack as other factors such as re-evaporation must also play a role, it is evident that the photolysis is an important process of nitrate loss in snowpack confirming recent isotopic evidence (Frey et al., 2009), but well constrained emission fluxes require the precise knowledge of the photodissociation quantum yield of nitrate/nitric acid present in natural snow.

Acknowledgements. We would like to thank Institute Polaire Paul-Emile Victor (IPEV) for logistical support in the field and staff at Dome $\mathrm{C}$ for all the support and help with this project, this study was partly funded by the program IPEV 1011 NITEDC. JLF and MDK thank NERC for support through grants NE/F0004796/1 and NE/F010788. This study benefited from support by project ANR OPALE (contract NT09 451281) and INSU-LEFE. MDK and JLF thank NERC FSF for support and expertise through grants 555.0608 and 584.0609 and Royal Holloway Earth Sciences research strategy fund awards.

Edited by: M. Ammann

\section{References}

Aoki, T., Hachikubo, A., and Hori, M.: Effects of snow physical parameters on shortwave broadband albedos, J. Geophys. Res., 108, 4616, doi:10.1029/2003jd003506, 2003.

Bauguitte, S. J.-B., Bloss, W. J., Evans, M. J., Salmon, R. A., Anderson, P. S., Jones, A. E., Lee, J. D., Saiz-Lopez, A., Roscoe, H. K., Wolff, E. W., and Plane, J. M. C.: Summertime $\mathrm{NO}_{\mathrm{x}}$ measurements during the CHABLIS campaign: can source and sink estimates unravel observed diurnal cycles?, Atmos. Chem. Phys. Discuss., 9, 20371-20406, doi:10.5194/acpd9-20371-2009, 2009.

Beaglehole, D., Ramanathan, B., and Rumberg, J.: The UV to IR transmittance of Antarctic snow, J. Geophys. Res. Atmos., 103, 8849-8857, doi:10.1029/97JD03604, 1998.

Beine, H. J., Amoroso, A., Domin, F., King, M. D., Nardino, M., Ianniello, A., and France, J. L.: Surprisingly small HONO emissions from snow surfaces at Browning Pass, Antarctica, Atmos. Chem. Phys., 6, 2569-2580, doi:10.5194/acp-6-2569-2006, 2006.

Blunier, T., Floch, G. L., Jacobi, H. W., and Quansah, E.: Isotopic view on nitrate loss in Antarctic surface snow, Geophys. Res. Lett., 32, L13501, doi:10.1029/2005GL023011, 2005.

Burkhart, J. F., Hutterli, M., Bales, R. C., and McConnell, J. R.: Seasonal accumulation timing and preservation of nitrate in firn at Summit, Greenland, J. Geophys. Res. Atmos., 109, D19302, doi:10.1029/2004jd004658, 2004.

Burkhart, J. F., Bales, R. C., McConnell, J. R., Hutterli, M. A., and Frey, M. M.: Geographic variability of nitrate deposition and preservation over the Greenland Ice Sheet, J. Geophys. Res. Atmos., 114, D06301, doi:10.1029/2008jd010600, 2008. 
Burley, J. D. and Johnston, H. S.: Ionic mechanisms for heterogeneous stratospheric reactions and ultraviolet photoabsorption cross-sections for $\mathrm{NO}_{2}^{+}, \mathrm{HNO}_{3}$, and $\mathrm{NO}_{3}^{-}$in Sulfuric-Acid, Geophys. Res. Lett., 19, 1359-1362, doi:10.1029/92GL01115, 1992.

Chu, L. and Anastasio, C.: Quantum yields of hydroxyl radical and nitrogen dioxide from the photolysis of nitrate on ice, J. Phys. Chem. A, 107, 9594-9602, doi:10.1021/jp0349132, 2003.

Conger, S. M. and McClung, D. M.: Comparison of density cutters for snow profile observations, J. Glaciol., 55, 163-169, 2009.

Davis, D., Nowak, J. B., Chen, G., Buhr, M., Arimoto, R., Hogan, A., Eisele, F., Mauldin, L., Tanner, D., Shetter, R., Lefer, B., and McMurry, P.: Unexpected high levels of NO observed at South Pole, Geophys. Res. Lett., 28, 3625-3628, 2001.

Davis, D., Chen, G., Buhr, M., Crawford, J., Lenschow, D., Lefer, B., Shetter, R., Eisele, F., Mauldin, L., and Hogan, A.: South Pole $\mathrm{NO}_{\mathrm{x}}$ Chemistry: an assessment of factors controlling variability and absolute levels., Atmos. Environ., 38, 5375-5388, 2004.

Davis, D. D., Seelig, J., Huey, G., Crawford, J., Chen, G., Wang, Y. H., Buhr, M., Helmig, D., Neff, W., Blake, D., Arimoto, R., and Eisele, F.: A reassessment of Antarctic plateau reactive nitrogen based on ANTO 2003 airborne and ground based measurements, Atmos. Environ., 42, 2831-2848, doi:10.1016/j.atmosenv.2007.07.039, 2008.

Dibb, J. E. and Fahnestock, M.: Snow accumulation, surface height change, and firn densification at Summit, Greenland: Insights from 2 years of in situ observation, J. Geophys. Res., 109, D24113, doi:10.1029/2003jd004300, 2004.

Dibb, J. E., Huey, L. G., Slusher, D. L., and Tanner, D. J.: Soluble reactive nitrogen oxides at South Pole during ISCAT 2000, Atmos. Environ., 38, 5399-5409, doi:10.1016/j.atmosenv.2003.01.001, 2004.

Dibb, J. E., Whitlow, S. I., and Arsenault, M.: Seasonal variations in the soluble ion content of snow at Summit. Greenland: Constraints from three years of daily surface snow samples, Atmos. Environ., 41, 5007-5019, 2007.

Doherty, S. J., Warren, S. G., Grenfell, T. C., Clarke, A. D., and Brandt, R. E.: Light-absorbing impurities in Arctic snow, Atmos. Chem. Phys., 10, 11647-11680, doi:10.5194/acp-1011647-2010, 2010.

Domine, F. and Shepson, P. B.: Air-snow interactions and atmospheric chemistry, Science, 297, 1506-1510, doi:10.1126/science.1074610, 2002.

Dubowski, Y., Colussi, A. J., and Hoffmann, M. R.: Nitrogen dioxide release in the $302 \mathrm{~nm}$ band photolysis of spray-frozen aqueous nitrate solutions. Atmospheric implications, J. Phys. Chem. A, 105, 4928-4932, doi:10.1021/jp0042009, 2001.

Dubowski, Y., Colussi, A. J., Boxe, C., and Hoffmann, M. R.: Monotonic increase of nitrite yields in the photolysis of nitrate in ice and water between 238 and 294 K, J. Phys. Chem. A, 106, 6967-6971, doi:10.1021/jp0142942, 2002.

Duggin, M. J. and Philipson, W. R.: Field measurement of reflectance: some major considerations, Appl. Opt., 21, 28332840, doi:10.1364/AO.21.002833, 1982.

Fierz, C., Armstrong, R. L., Durand, Y., Etchevers, P., Greene, E., McClung, D. M., Nishimura, K., Satyawali, P. K., and Sokratov, S. A.: The International classification for seasonal snow on the ground, IHP-VII Technical documents in Hydrology No 83,
IACS Contribution No 1, UNESCO-IHP, Paris, France, 2009.

Fisher, F. N., King, M. D., and Lee-Taylor, J.: Extinction of UVvisible radiation in wet midlatitude (maritime) snow: Implications for increased $\mathrm{NO}_{\mathrm{x}}$ emission, J. Geophys. Res. Atmos., 110, D21301, doi:10.1029/2005JD005963, 2005.

France, J. L., King, M. D., and Lee-Taylor, J.: The importance of considering depth-resolved photochemistry in snow: a radiative-transfer study of $\mathrm{NO}_{2}$ and $\mathrm{OH}$ production in Ny-Alesund snowpacks, J. Glaciol., 56, 655-663, doi:10.3189/002214310793146250, 2010.

France, J. L., King, M. D., Lee-Taylor, J., J., B. H., Ianniello, A., Macarthur, A., and Domine, F.: A field and radiative-transfer study of the optical properties of Svalbard (Ny-Ålesund) snowpacks: Predictions of in-snow $\mathrm{NO}_{2}$ and $\mathrm{OH}$ photochemical production rates, J. Geophys. Res. Earth Surf, [surface], in press, doi:10.1029/2011JF002019, 2011.

France, J. L., King, M. D., Lee-Taylor, J., Beine, H. J., Ianniello, A., Domine, F., and MacArthur, A.: Calculations of in-snow $\mathrm{NO}_{\mathrm{x}}$ and $\mathrm{OH}$ radical photochemical production and photolysis rates: A field and radiative-transfer study of the optical properties of Arctic (Ny-Ålesund, Svalbard) snow, J. Geophys. Res., doi:10.1029/2011JF002019, in press, 2011.

Frey, M. M., Savarino, J., Morin, S., Erbland, J., and Martins, J. M. F.: Photolysis imprint in the nitrate stable isotope signal in snow and atmosphere of East Antarctica and implications for reactive nitrogen cycling, Atmos. Chem. Phys., 9, 8681-8696, doi:10.5194/acp-9-8681-2009, 2009.

Gallet, J.-C., Domine, F., Arnaud, L., Picard, G., and Savarino, J.: Vertical profile of the specific surface area and density of the snow at Dome C and on a transect to Dumont D'Urville, Antarctica albedo calculations and comparison to remote sensing products, The Cryosphere, 5, 631-649, doi:10.5194/tc-5-631-2011, 2011.

Gardiner, B. G. and Martin, T. J.: On measuring and modelling ultraviolet spectral irradiance, in: Current problems in atmospheric radiation, edited by: Smith, W. L. and Stamnes, K., Deepak Hampton, Virginia, 917-920, 1997.

Gay, M., Fily, M., Genthon, C., Frezzotti, M., Oerter, H., and Winther, J.-G.: Snow grain-size measurements in Antarctica, J. Glaciol., 48, 527-535, 2002.

Grannas, A. M., Jones, A. E., Dibb, J., Ammann, M., Anastasio, C., Beine, H. J., Bergin, M., Bottenheim, J., Boxe, C. S., Carver, G., Chen, G., Crawford, J. H., Domin, F., Frey, M. M., Guzmn, M. I., Heard, D. E., Helmig, D., Hoffmann, M. R., Honrath, R. E., Huey, L. G., Hutterli, M., Jacobi, H. W., Kln, P., Lefer, B., McConnell, J., Plane, J., Sander, R., Savarino, J., Shepson, P. B., Simpson, W. R., Sodeau, J. R., von Glasow, R., Weller, R., Wolff, E. W., and Zhu, T.: An overview of snow photochemistry: evidence, mechanisms and impacts, Atmos. Chem. Phys., 7, 4329-4373, doi:10.5194/acp-7-4329-2007, 2007.

Grenfell, T. C. and Maykut, G. A.: The optical properties of ice and snow in the Arctic basin, J. Glaciol., 10, 445-463, 1977.

Grenfell, T. C., Warren, S. G., and Mullen, P. C.: Reflection of solarradiation by the Antarctic snow surface at ultraviolet, visible, and near-infrared wavelengths, J. Geophys. Res. Atmos., 99, 1866918684, doi:10.1029/94JD01484, 1994.

Hastings, M. G., Steig, E. J., and Sigman, D. M.: Seasonal variations in $\mathrm{N}$ and $\mathrm{O}$ isotopes of nitrate in snow at Summit, Greenland: Implications for the study of nitrate in 
snow and ice cores, J. Geophys. Res. Atmos., 109, D20306, doi:10.1029/2004JD004991, 2004.

Hoffer, A., Gelencsér, A., Guyon, P., Kiss, G., Schmid, O., Frank, G. P., Artaxo, P., and Andreae, M. O.: Optical properties of humic-like substances (HULIS) in biomass-burning aerosols, Atmos. Chem. Phys., 6, 3563-3570, doi:10.5194/acp-6-3563-2006, 2006.

Honrath, R. E., Lu, Y., Peterson, M. C., Dibb, J. E., Arsenault, M. A., Cullen, N. J., and Steffen, K.: Vertical fluxes of NOx, HONO, and $\mathrm{HNO}_{3}$ above the snowpack at Summit, Greenland, Atmos. Environ., 36, 2629-2640, doi:10.1016/S1352-2310(02)00132-2, 2002.

Jones, A. E., Weller, R., Anderson, P. S., Jacobi, H. W., Wolff, E. W., Schrems, O., and Miller, H.: Measurements of $\mathrm{NO}_{\mathrm{x}}$ emissions from the Antarctic snowpack, Geophys. Res. Lett., 28, 1499-1502, doi:10.1029/2000GL011956, 2001.

Jouzel, J., Masson-Delmotte, V., Cattani, O., Dreyfus, G., Falourd, S., Hoffmann, G., Minster, B., Nouet, J., Barnola, J. M., Chappellaz, J., Fischer, H., Gallet, J. C., Johnsen, S., Leuenberger, M., Loulergue, L., Luethi, D., Oerter, H., Parrenin, F., Raisbeck, G., Raynaud, D., Schilt, A., Schwander, J., Selmo, E., Souchez, R., Spahni, R., Stauffer, B., Steffensen, J. P., Stenni, B., Stocker, T. F., Tison, J. L., Werner, M., and Wolff, E. W.: Orbital and millennial Antarctic climate variability over the past 800,000 years, Science, 317, 793-796, doi:10.1126/science.1141038, 2007.

King, M. D. and Simpson, W. R.: Extinction of UV radiation in Arctic snow at Alert, Canada $\left(82^{\circ} \mathrm{N}\right)$, J. Geophys. Res. Atmos., 106, 12499-12507, doi:10.1029/2001JD900006, 2001.

King, M. D., France, J. L., Fisher, F. N., and Beine, H. J.: Measurement and modelling of UV radiation penetration and photolysis rates of nitrate and hydrogen peroxide in Antarctic sea ice: An estimate of the production rate of hydroxyl radicals in first-year sea ice, J. Photochem. Photobiol., A, 176, 39-49, doi:10.1016/j.jphotochem.2005.08.032, 2005.

Lee-Taylor, J. and Madronich, S.: Calculation of actinic fluxes with a coupled atmosphere-snow radiative transfer model, J. Geophys. Res. Atmos., 107, 4796, doi:10.1029/2002JD002084, 2002.

Legrand, M., Preunkert, S., Jourdain, B., Gallée, H., Goutail, F., Weller, R., and Savarino, J.: Year-round record of surface ozone at coastal (Dumont d'Urville) and inland (Concordia) sites in East Antarctica, J. Geophys. Res., 114, D20306, doi:10.1029/2008jd011667, 2009.

McPeters, R. D., Krueger, A. J., Bhartia, P. K., and Herman, J. R.: Earth Probe Total Ozone Mapping Spectrometer (TOMS) data products user's guide, NASA Reference Publication, 1998.

Munneke, P. K., Reijmer, C. H., van den Broeke, M. R., KoenigLanglo, G., Stammes, P., and Knap, W. H.: Analysis of clear-sky Antarctic snow albedo using observations and radiative transfer modeling, J. Geophys. Res. Atmos., 113, D17118, doi:10.1029/2007jd009653, 2008.

Neff, W., Helmig, D., Grachev, A., and Davis, D.: A study of boundary layer behavior associated with high NO concentrations at the South Pole using a minisodar, tethered balloons and sonic anemometer, Atmos. Environ., 42, 2762-2779, doi:10.1016/j.atmosenv.2007.01.033, 2008.

Oncley, S. P., Buhr, M., Lenschow, D. H., Davis, D., and Semmer, S. R.: Observations of summertime NO fluxes and boundarylayer height at the South Pole during ISCAT 2000 using scalar similarity, Atmos. Environ., 38, 5389-5398, 2004.
Phillips, G. J. and Simpson, W. R.: Verification of snowpack radiation transfer models using actinometry, J. Geophys. Res. Atmos., 110, D08306, doi:10.1029/2004JD005552, 2005.

Picard, G., Arnaud, L., Domine, F., and Fily, M.: Determining snow specific surface area from near-infrared reflectance measurements: Numerical study of the influence of grain shape, Cold Reg. Sci. Technol., 56, 10-17, doi:10.1016/j.coldregions.2008.10.001, 2009.

Rothlisberger, R., Hutterli, M. A., Sommer, S., Wolff, E. W., and Mulvaney, R.: Factors controlling nitrate in ice cores: Evidence from the Dome C deep ice core, J. Geophys. Res. Atmos., 105, 20565-20572, 2000.

Rothlisberger, R., Hutterli, M. A., Wolff, E. W., Mulvaney, R., Fischer, H., Bigler, M., Goto-Azuma, K., Hansson, M. E., Ruth, U., Siggaard-Andersen, M. L., and Steffensen, J. P.: Nitrate in Greenland and Antarctic ice cores: a detailed description of postdepositional processes, in: Annals of Glaciology, Ann. Glaciol., 35, 209-216, 2002.

Scambos, T. A., Haran, T. M., Fahnestock, M. A., Painter, T. H., and Bohlander, J.: MODIS-based Mosaic of Antarctica (MOA) data sets: Continent-wide surface morphology and snow grain size, Remote Sens. Environ., 111, 242-257, 2007.

Slusher, D. L., Neff, W. D., Kim, S., Huey, L. G., Wang, Y., Zeng, T., Tanner, D. J., Blake, D. R., Beyersdorf, A., Lefer, B. L., Crawford, J. H., Eisele, F. L., Mauldin, R. L., Kosciuch, E., Buhr, M. P., Wallace, H. W., and Davis, D. D.: Atmospheric chemistry results from the ANTCI 2005 Antarctic plateau airborne study, J. Geophys. Res. Atmos., 115, D07304, doi:10.1029/2009jd012605, 2010.

Stamnes, K., Tsay, S. C., Wiscombe, W., and Jayaweera, K.: Numerically stable algorithm for Discrete-Ordinate-Method Radiative-Transfer in multiple-scattering and emitting layered media, Appl. Opt., 27, 2502-2509, doi:10.1364/AO.27.002502, 1988.

Wagenbach, D., Graf, W., Minikin, A., Trefzer, U., Kipfstuhl, J., Oerter, H., and Blindow, N.: Reconnaissance of chemical and isotopic firn properties on top of Berkner Island, Antarctica, Ann. Glaciol., 20, 307-312, 1994.

Wang, Y. H., Choi, Y., Zeng, T., Davis, D., Buhr, M., Huey, L. G., and Neff, W.: Assessing the photochemical impact of snow $\mathrm{NO}_{\mathrm{x}}$ emissions over Antarctica during ANTCI 2003, Atmos. Environ., 41, 3944-3958, doi:10.1016/j.atmosenv.2007.01.056, 2007.

Warneck, P., and Wurzinger, C.: Product quantum yields for the 305-nm photodecomposition of nitrate in aqueous solution, J. Phys. Chem., 92, 6278-6283, doi:10.1021/j100333a022, 1988.

Warren, S. G.: Optical-Properties of Snow, Rev. Geophys., 20, 6789, doi:10.1029/RG020i001p00067, 1982.

Warren, S. G. and Brandt, R. E.: Optical constants of ice from the ultraviolet to the microwave: A revised compilation, J. Geophys. Res., 113, D14220, doi:10.1029/2007jd009744, 2008.

Warren, S. G. and Wiscombe, W. J.: A Model for the Spectral Albedo of Snow.2. Snow Containing Atmospheric Aerosols, J. Atmos. Sci., 37, 2734-2745, 1980.

Warren, S. G. and Wiscombe, W. J.: Dirty snow after nuclear war, Nature, 313, 467-470, 1985.

Warren, S. G., Brandt, R. E., and Grenfell, T. C.: Visible and near-ultraviolet absorption spectrum of ice from transmission of solar radiation into snow, Appl. Opt., 45, 5320-5334, doi:10.1364/AO.45.005320, 2006. 
Wiscombe, W. J. and Warren, S. G.: A Model for the Spectral Albedo of Snow.1. Pure Snow, J. Atmos. Sci., 37, 2712-2733, 1980 .

Wolff, E. W., Jones, A. E., Martin, T. J., and Grenfell, T. C.: Modelling photochemical NOx production and nitrate loss in the upper snowpack of Antarctica, Geophys. Res. Lett., 29, 1944, doi:10.1029/2002GL015823, 2002.

Wolff, E. W., Barbante, C., Becagli, S., Bigler, M., Boutron, C. F., Castellano, E., de Angelis, M., Federer, U., Fischer, H., Fundel, F., Hansson, M., Hutterli, M., Jonsell, U., Karlin, T., Kaufmann, P., Lambert, F., Littot, G. C., Mulvaney, R., Rothlisberger, R., Ruth, U., Severi, M., Siggaard-Andersen, M. L., Sime, L. C., Steffensen, J. P., Stocker, T. F., Traversi, R., Twarloh, B., Udisti, R., Wagenbach, D., and Wegner, A.: Changes in environment over the last 800,000 years from chemical analysis of the EPICA Dome C ice core, Quat. Sci. Rev., 29, 285-295, doi:10.1016/j.quascirev.2009.06.013, 2010.
Zellner, R., Exner, M., and Herrmann, H.: Absolute OH quantum yields in the laser photolysis of nitrate, nitrite and dissolved $\mathrm{H}_{2} \mathrm{O}_{2}$ at 308 and $351 \mathrm{~nm}$ in the temperature range $278-353 \mathrm{~K}, \mathrm{~J}$. Atmos. Chem., 10, 411-425, doi:10.1007/bf00115783, 1990.

Zhu, C., Xiang, B., Chu, L. T., and Zhu, L.: 308 nm Photolysis of Nitric Acid in the Gas Phase, on Aluminum Surfaces, and on Ice Films, J. Phys. Chem. A, 114, 2561-2568, doi:10.1021/jp909867a, 2010. 